\title{
The Effect of Product Diversification on the Purchase Decision of Telkomsel Loop Simcards (Case Study of Bandung State Polytechnic Students)
}

\author{
Henny Noviany \\ Sekolah Tinggi Ilmu Ekonomi Pasundan, Indonesia, Jawa Barat
}

\begin{abstract}
This study aims to determine and analyze the Effect of Product Diversification on the Purchase Decision of Telkomsel Loop Simcards (Case Study in Bandung State Polytechnic Students). The research method used in this research is a descriptive analysis and verification method with a population of 100 students by using accidental sampling technique by providing a link to fill out the questionnaire via Google Drive. The data analysis technique used is the Correlation Analysis Technique to determine the degree of closeness of the relationship between variables. The results showed that the direct effect of Product Diversification was 3.97. The indirect effect of the Purchasing Decision is 4.13. The test results are known to the constant value (a) of 2.537 and partially Product Diversification variable influences the Purchasing Decision variable. It was concluded that the effect of Product Diversification on Purchasing Decisions showed a positive regression coefficient of 0.468 .
\end{abstract}

Keywords: Product Diversification, Purchase Decisions, Halo Simcards, Loop Simcards. 


\section{INTRODUCTION}

Today, world trade leads to a form of global trade. A trade that no longer recognizes national boundaries in the geographical sense as a barrier to trade between market participants. Indonesia as one of the competent countries in the global market is demanded to be able to compete with other countries. At present the development of mobile phone usage in the world is increasing rapidly, and Indonesia ranks sixth in the number of mobile phone users in Indonesia as much as 99.68\% of the population in Indonesia (en.wikipedia.org, 2013).

With this competition requires every company to always compete in attracting consumers by implementing appropriate strategies in meeting sales volume targets. Innovation that can meet the needs and tastes of consumers is absolutely necessary if business people do not want to lose their customers and grow demand for their products. Maintaining and even fostering new requests is certainly not an easy matter for business people.

Telkomsel is one of the providers of cellular telecommunications services with extensive network coverage throughout Indonesia and Telkomsel services include voice, data and other added value services (Telkomsel, 2014). Telkomsel is also a company engaged in the field of cellular telecommunications services that also faces competition. One of them, this company is required to implement the right marketing strategy in order to achieve the targets that have been set.

The achievements of Telkomsel in its performance, namely the 2014 TOP BRAND INDEX telecommunications category, prepaid GSM SIM CARD stated that Telkomsel is ranked top with a presentation of $25.90 \%$ (TOP BRAND, 2014).

For that, the company must be right in choosing marketing strategies that can play a role in winning the competition. There are various choices of marketing strategies that can be applied by companies. One strategy that can be used by companies is a product diversification strategy. Product diversification aims to meet the desires and needs of different consumers, other than that as a form of investment for the company.

In the decision making model, consumers involve all aspects of influence and cognition in making purchasing decisions, namely knowledge, meaning, trust arising from memory, and the attention and understanding processes involved in translating new information in the environment. But the core of consumer decision making is actually the process of integrating knowledge combining to evaluate two or more alternative behaviors and choosing one of them, where the results of this integration process are referred to as choices presented cognitively as behavioral desires.

There are five stages in purchasing decision making namely problem recognition, information search, alternative evaluation, purchasing decisions and post-purchase behavior. The purchase decision is one stage where consumers actually buy a product.

Consumer product choices and service choices are changing constantly. Consumer behavior describes how consumers make purchasing decisions and understand how consumers make purchasing decisions that can help marketing managers in many ways including redesigning products to meet criteria or formulating appropriate marketing mix designs. Consumer behavior is very decisive in the purchase decision making process.

\section{RESULTS AND DISCUSSION}

Based on the results of data processing, the description of the product diversification variable has an average score of 3.97. The average score in either category. This shows that respondents gave a good rating on the product diversification variable (X) LOOP. 
However, when viewed from the dimensions that exist in the product diversification variable, it will appear that the highest dimension is the score is the load dimension of increasing sales by diversifying products for new markets with the indicator of providing facilities according to market needs, namely having a strong signal. While the lowest score is the dimension of new product development for new markets on the indicator of issuing new economical products. The description of the purchase decision variable $(Y)$ has an average score of 4.13. The average is in accordance with the interpretation criteria included in the good condition category. This shows that respondents gave a good assessment of the purchase decision variable $(Y)$ LOOP products.

When viewed from the dimensions of the purchase decision variable $(Y)$, it will appear that the highest dimension of the score is the dimension of finding information about the product or service needed in the indicator of information search about product prices, while the lowest score is the dimension of post-purchase behavior, namely on the indicator make a repeat purchase and recommend the product to others.

Based on the results of data processing, it appears that the value of the level of purchase decisions reached was only 2,537. In addition, for each addition of one product diversification number with a positive positive regression coefficient, the purchasing decision will increase by 0.468 .

Table 1

Variable Intercorrelation Coefficient

\begin{tabular}{|l|c|c|}
\hline Variabel & Rata - Rata & Kriteria \\
\hline Diversifikasi Produk $(\mathrm{X})$ & 3,97 & Baik \\
\hline Keputusan Pembelian $(\mathrm{Y})$ & 4,13 & Baik \\
\hline
\end{tabular}

Source: Data Processed 2016

Figure 1

Correlation Results Between Variables

Correlations

\begin{tabular}{|ll|r|r|}
\hline & X & Y \\
\hline \multirow{4}{*}{ X } & Pearson Correlation & 1 & $.468^{* *}$ \\
& Sig. (2-tailed) & & .000 \\
N & 100 & 100 \\
& Pearson Correlation & $.468^{* *}$ & 1 \\
Y Sig. (2-tailed) & .000 & \\
& N & 100 & 100 \\
\hline
\end{tabular}

${ }^{*}$. Correlation is significant at the 0.01 level (2-tailed).

Source: Data Processed SPSS 22 
Figure 2

Regression Analysis Results

Coefficients $^{\mathrm{a}}$

\begin{tabular}{|c|c|c|c|c|c|c|}
\hline \multirow{2}{*}{\multicolumn{2}{|c|}{ Model }} & \multicolumn{2}{|c|}{ Unstandardized Coefficients } & Standardized & \multirow[t]{2}{*}{$\mathrm{T}$} & \multirow[t]{2}{*}{ Sig. } \\
\hline & & $B$ & Std. Error & Beta & & \\
\hline \multirow{2}{*}{1} & (Constant) & 2.537 & .306 & & 8.289 & .000 \\
\hline & $X$ & .402 & .077 & .468 & 5.241 & .000 \\
\hline
\end{tabular}

Source: Data Processed 2016

\section{CONCLUSSION}

Based on the description and discussion of the results of research on the effect of awareness of product diversification (X) on the purchase decision of case studies in Bandung State Polytechnic Students, the authors can draw the following conclusions:

1. Relating to product diversification $(X)$ has the peak dimension of thought. The results showed that the average score. The average is in accordance with the interpretation criteria included in either category. This shows that respondents gave a good assessment of the variable diversification of LOOP products.

2. The purchase decision variable $(Y)$ has an average score. The average score is in accordance with the interpretation criteria included in either category. This shows that respondents gave a good assessment of the purchase decision variable (Y) LOOP products. The highest average dimension is the dimension of finding information about products and services needed in the indicator of information seeking about product prices, while the lowest score is the dimension of post-purchase behavior that is on the indicator of repurchasing and recommending products to others. This shows that for consumers LOOP products are very important to find information about the product before making a purchase.

3. Effect of Product Diversification on Purchasing Decisions has a score of 0.486. This shows that respondents gave a relatively good rating.

\section{REFERENCE}

Cooper, D. and P. S. Schindler (2006). Marketing Research. New York, McGraw-Hill.

Foursquare (2013). Retrieved 24 May, 2014, from https://foursquare.com/v/metro-indahmall/4c95b57958d4b60c83253529.

Gronroos, C. (2004). "The relationship marketing process: communication, interaction, dialogue, value." Journal of Business E Industrial Marketing19: 99-113.

Harker, M. J. and J. Egan (2006). "The past, present, and future of relationship marketing." Journal of Marketing Management22: 215-242.

Hoffman, D. K. and J. E. G. Bateson (2008). Services Marketing Concepts, Strategies, E Cases. Mason, Cengage Learning.

Kotler, P. and G. Armstrong (2006). Principles of Marketing. New Jersey, Pearson Education.

Kotler, P. and G. Armstrong (2010). Principles of Marketing. New Jersey, Pearson Education.

Kotler, P. and K. L. Keller (2012). Marketing Management. London, Pearson Education Limited.

Lind, Marchal, et al. (2012). Statistical Technique in Business and Economics, McGraw-Hill, Irwin.

Lovelock, C. H. and L. K. Wright (2007). Manajemen Pemasaran Jasa. Jakarta, PT. Indeks. 
Lupiyoadi, R. and A. Hamdani (2004). Manajemen Pemasaran Jasa. Jakarta, Salemba Empat.

Slovin(2004). Marketing Research: An Applied Orientation. New Jersey, Pearson Education International.

Miciak, A. and M. Desmarais (2001). "Benchmarking service quality performance at business to business and business to consumer call centers." Lournal of Business $\mathcal{E}$ Industrial Marketing16(5): 340-353.

MIM (2014). "Metro Indah Mall." Retrieved 24 May, 2014, from http://www.metroindahmall.com/en/.

Nasution, M. N. (2005). Manajemen Mutu Terpadu. Jakarta, Ghalia Indonesia.

Pallant, J. (2013). SPSS Survival Manual, McGraw Hill.

Palmer, A. (2004). Introduction to Marketing: Theory And Practice., Oxford University.

Parry, S., J. Rowley, et al. (2012). "Customer-perceived value in business to business relationships: a study of software customers." Lournal of Marketing Management28: 887911.

Simamora, B. (2004). Riset Pemasaran Falsafah, Teori, dan Aplikasi. Jakarta, PT Gramedia Pustaka Utama.

Sugiama, G. (2008). Metode Riset Bisnis dan Manajemen. Bandung, CV. Guardaya Intimarta.

Sunyoto, D. (2012). Konsep Dasar Riset Pemasaran dan Perilaku Konsumen. Yogyakarta, CAPS.

Theron, E. and N. S. Terblanche (2010). "Dimensions of relationship marketing in business to business financial services." International Journal of Market Research52(3): 383-402.

Vitale and Giglierano (2002). Business to Business Marketing: Analysis \& Practice in a Dynamic Environment. United States, South Western.

Ward, T. and T. S. Dagger (2007). "The compelxity of relationship marketing for service customers." Journal of Services Marketing21: 281-290.

Zeithaml, V. A., M. J. Bitner, et al. (2006). Service Marketing, Integrating Customer Focus Across The Firm. New York, McGraw-Hill. 